\title{
Sanat Galerisi Ziyaretlerinde Gerçekleştirilen Aktif Öğrenme Etkinliklerinin 4-6 Yaş Arası Çocukların Görsel Algılarına
} Etkisi

\author{
The Influence of Active Learning Activities on Visual Perceptions of Children \\ Aged Between 4 and 6 During Art Gallery Visits
}

\section{Ŏguz Dilmaç}

Prof. Dr., İzmir Kâtip Çelebi Üniversitesi, Sanat ve Tasarım Fakültesi, Temel Eğitim Bölümü

email: oguz.dilmac@ikc.edu.tr (DORCID ID: https://orcid.org/0000-0002-6778-6912

\section{Eyüp Emrah İnal}

Öğretmen, Erzurum Hilalkent Anadolu Lisesi

email: eyupemrah@gmail.com (DORCID ID: https://orcid.org/0000-0001-6540-4872

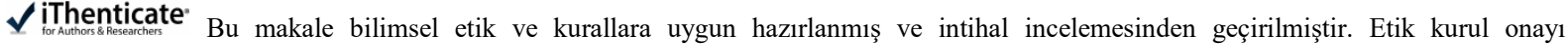
gerektirmemektedir.

Atıf (APA 6)/To cite this article

Dilmaç, O., \& İnal, E. E. (2020). Sanat galerisi ziyaretlerinde gerçekleştirilen aktif öğrenme etkinliklerinin 4-6 yaş arası çocukların görsel algılarına etkisi. Atatürk Üniversitesi Güzel Sanatlar Enstitüsü Dergisi, 26(45), 499-510. doi: https://doi.org/10.35247/ataunigsed.730418
}

Makale Gönderim Tarihi/Received: 01/05/2020

Makale Kabul Tarihi/Accepted: 13/10/2020

Makale Yayın Tarihi/Published: 22/10/2020

Research Article/Araștırma Makalesi

Öz

$\mathrm{Bu}$ araştırmada sanat galerisi ziyareti sürecinde aktif öğrenme etkinliklerinin, anaokuluna devam eden 4-6 yas arası çocukların Frostig görsel algılarına etkisini incelemek amaçlanmıştır. $\mathrm{Bu}$ çalıșmada dört aşamaya yer verilerek: içerik toplama, verilerin derlenmesi, veri analizi ve değerlendirme yapılmıştır. Araştırma grubu, Erzurum ili Palandöken ilçesi Millî Eğitim Bakanlığı'na bağlı Zübeyde Hanım Anaokulunun anasınıfına devam eden 15'i deney, 15'i kontrol grubu olmak üzere 30 öğrenciden olușmaktadır. Nicel araștırma yöntemlerinden deneysel desenin kullanıldığ bu çalışmada ön test son test kontrol gruplu çalışma deseni kullanılmıştır. Veri toplama aracı olarak Frostig tarafından geliștirilen "Frostig Görsel Alg1 Testi" kullanılmış olup istatistiksel verilerin çözümlemeleri SPSS 22.0 istatistik programı ile yapılmıștır. Araștırmada elde edilen sonuçlar değerlendirildiğinde; test genelinde alınan puana göre son test toplam puanlarının sıra ortalaması dikkate alındığında kontrol grubunun puanının deney grubu puanına göre düșük olduğu görülmüştür. Deney grubunda ön test ve son test sonuçları arasında istatistiksel olarak anlamlı bir farklılığa rastlanmıştır.

Anahtar kelimeler: Sanat Galerisi, Aktif Öğrenme, Görsel Alg1

\begin{abstract}
The aim of this study is to examine the influence of active learning activities on the Frostig visual perception of children aged between 4 and 6 attending kindergarten during art gallery visit. This study is divided into four stages, which are collection of data, compilation of data, data analysis and evaluation. The research group consists of 30 students, from Zubeyde Hanim Kinder garden of the Ministry of National Education in Palandoken district, Erzurum, 15 of which are in the experimental group and the rest is in the control group. In this study in which experimental design from quantitative research method was used pre-test posttest control group study design was used. As a data collection tool "Frostig Visual Perception Test" developed by Frostig was used and the analysis of statistical data was conducted by SPSS 22.0 statistic program. When the obtained results of the study were evaluated, it was observed that when the average of the post-test total scores were taken into account, the score of control group was lower than the experimental group according to the general test score. A statistically meaningful difference was observed between the pre-test and post-test results in the experimental group.the pre-test and post-test results in the experimental group.
\end{abstract}

Keywords: Art Gallery, Active Learning, Visual Perception

\section{Giriş}

İnsanoğlu doğumundan itibaren duyuları yardımı ile etrafını algılamaya başlar. Algı sözcüğü Latince'de 'almak, yakalamak, tutmak' anlamına gelen 'capere' sözcüğünden gelmiștir (Burunner ve Tanker, 1978, s. 89). Literatürde çeşitli tanımları bulunan algı; bilim ve psikoloji alanlarında, duyusal bilginin alınması, yorumlanması, seçilmesi ve düzenlenmesi anlamına gelmektedir. Algı, dış dünyanın ve bireyin iç dünyası ile aralarında kurulan nedensonuç ilişskisidir (Ertan, 2013). Diğer bir tanımı ise, duyular yoluyla uyarıların bellekte yorumlanması, açıklanması ve anlam kazanmasıdır (Bilir ve Alpaslan, 1977). Yapılan bu tanımların ortak yanı algının tüm duyu organları ile gerçekleştirilen nesneleri, olayları ve durumları anlamlandırma süreci olduğudur. $\mathrm{Bu}$ süreç içerinde bireyin gördüğünü kavrayıp, bilgiyi işleyerek yorumlaması ise görsel algıyı oluşturmaktadır. Görsel algı becerisi, çocuklara okumayı, yazmayı, hecelemeyi, aritmetik hesapları yapmayı geliştirmekte ve okulda başarılı olmaları için gerekli diğer yeteneklerinin tümünü ilerletmelerine yardımcı olmaktadır (Frostig, 1968). Görsel algı becerisi yüksek çocukların, şekilleri eşleştirmede, renkleri tanımada ve okuma becerilerinde yaşıtlarına göre daha başarılı olduğu bilinmektedir (Marriott, 2000). 
Okul öncesi dönemdeki çocukların görsel algılamada bir sorun varsa bu soruna ilişkin altta yatan problemlerin geç kalınmadan tespit edilerek eksiklerinin tamamlanması çocuğun gelişimi, özellikle de bilişsel gelişimi için büyük bir önem taşımaktadır. Görsel algıdaki bir eksiklik veya engel durumu, öğrenmede sorunlar doğuracaktır. Bu sorunlar özellikle çocukların benzer harfleri ve benzer sözcükleri karıştırması, okumayı yazmayı ve matematik yeteneklerini geliştirememenin yanı sıra çizim ve yazım becerilerinde de çocuğun gelişimini sürdürememesine neden olmaktadır (Gal ve Linchevski, 2010; Mangır ve Çağatay, 1990; Rosenblum, 2006; Sortor ve Kulp, 2003). Bunların yanı sıra algı gelişiminin ön koşulu olan şekil-zemin ayrımını da yapamamaktadırlar. Oysa özellikle 4 yaş çocuklarında görsel algı becerileri istenilen düzeydeyse şekil içerisinde bulunan bir başka şekil, birbiri üstüne gelen şekiller, geometrik şekiller ve ağacın içine gizlenmiş kuşlar gibi gerçek şekilleri de sorunsuz bir biçimde ayırt edebilirler. Burada altı çizilmesi gereken hususlardan biri de çocukların algılarının ilgilerini çeken uyaranlara göre değişebilmesidir. Bu noktada çocuklarda algıda seçicilik söz konusu olduğundan ilgilerini çekmeyen bir uyarıcıyı dikkate almayabilirler. Bunların yanı sıra çocuklar nesneleri kendilerinden uzaklaştıkça onun ne olduğunu ayırt edemeyebilirler. Çocuklar bir masayı ister uzak ister yakında olsun büyüklüğünü yetişkinlerin algıladıkları gibi algılayamazlar ve bu konuda sıkıntı yaşarlar. Nesneleri farklı uzaklıklardan gözüne yansıyan görüntüleri ayarlayıp algılamadaki değişikleri fark edemezler. Fakat öğrenmeler sonucunda: kendisine yaklaşıp uzaklaşan nesnenin aynı olup olmadığını doğru algılamaya başlarlar. $\mathrm{Bu}$ nedenle sanatsal etkinliklerin bu doğrultuda düzenlenmesi geometrik üç boyutlu cisimlerle başlayıp gerçek nesnelere dokunarak büyüklüklerini tahmin etmeleri istenebilir. Özellikle çocuğun görsel duyusunun yanı sıra, dokunma duyusu da başlangıçta nesnelerin farklı uzaklıklarda olsalar bile aynı olduklarını kavramalarında yardımcı olacaktır. Çocukların görsel algısını etkileyen diğer bir hususta küçük yaşlardaki çocukların kendi görüş ve duygularını başkalarının da kesinlikle kendisi gibi gördüğü ve düşündüğünü zannetmesidir. Bir kâğıda çizdiği elmayı, elma olmadığını dile getirilirse çocuk bu konuda sinirlenebilir. Haliyle çizdiği elma herkesin elma olarak gördüğüne inanır (Fişek ve Y1ldirım, 1983).

Birçok araştırmacı, çocuğun algısal gelişimini belirleyebilmenin en önemli aracı olarak çocuk çizimlerini göstermektedir (Athey, 1990; Matthews, 2003; Trevarthen, 1995; Wolf ve Fucigna, 1983). Sanatta öğrenme, alg1, yaratıcılık ve yansıtmayla ifade ederek gerçekleşir. Göz ve zihin arasındaki ilişki ve bağlantıyı fark eden Rudolf Arnheim, algının kavramanın temeli olduğunu dile getirmiş ve algıyı görsel sanatlar ve görsel algılama alanlarıyla ilişkilendirmiştir. Arnheim, çocuk yaşlarda çizim uygulamalarının beceri ve öğrenim açısından eğitim sürecinde önemli bir yere sahip olduğunu dile getirmektedir. Yani yaşantımızda önemli bir yeri olan algılamanın geliştirilmesi için sanat eğitiminin çok önemli bir yeri ve sonucu olduğunu dile getirmiştir (aktaran Sahasrabudhe, 2006). Bu etkinlikler çocuğun algısını etkileyen bilişsel, dil, sosyal ve duygusal gelişiminde de önemli rol oynamaktadır. Görsel algılamayı geliştirmek aslında çaba gerektiren bir süreçtir. Aynı zamanda çevremizdeki nesnelere farklı bir bakış açısından yaklaşabilmeye olanak sağlayan algısal, içgüdüsel bir gereksinim sonucudur (Artut, 2013).

Okulöncesi dönem, çocukların fiziksel, bilişsel ve sosyal gelişimlerinde önemli değişimin olduğu dönemdir ve bu gelişim alanları birbirleriyle etkileşim içindedir (Gander ve Gardiner, 2014). Daha ileri yaşlarda bu çocuklar, içinde barındırdıkları bütün duygularını kullanmak isteyecek ve davranışları arasında belli bir ereğe en iyi biçimde ulaşabilmek için çevresindeki nesneleri tanımaya, ayırt etmeye ve zihin fonksiyonlarını geliştirmeye başlayacaklardır. Bunun temelinde gelişimi hızlı olan çocuk yaş gruplarında bilişsel, sosyal, duyusal alanların da büyük bir öneme sahip olması yatmaktadır. Görsel algı, bireyler için önemli bir kavrama yeteneğidir. Görsel algılama problemi 3-7 yaşları arasında görülür ve sorunlu olan çocuklar akranlarından geri kaldıkları için özgüven kısıtlaması yaşarlar. Bu çocukların görsel algılarında oluşan problemlerin erkenden belirlenmesi ve uygun önlemlerle çözüm yollarının aranarak sorunlara derhal müdahale edilmesi, problemlerin kalıcı olmaması için oldukça önemlidir.

Okul öncesi dönemde çocukların görsel algılarının gelişiminde sanat etkinliklerinin önemli bir yeri vardır. Çocuk özellikle resim etkinlikleri sırasında el ve göz koordinasyonu yaparak olayları, nesneleri ve duygularını resmeder. Basit gibi görünen fakat etkileri anlamında çocuğun gelişimi için oldukça önemli bu etkinlikler sırasında çocuklar, görsel algılarına yönelik birtakım ipuçları verir. Alanında yetkin ve uzman bir eğitimci bu resimlere bakarak çocuğun karakterine ilişkin verdikleri bilgiyi analiz edebilir ve uygun yaklaşımlar gösterebilirler.

Bunun yanı sıra eğitimciler, öğrenme sürecinde öğrencilerin doğal merak ve istek duygularından yararlanarak, öğrencilere araştırma, keşfetme ve sorun çözmeyi teşvik edecek sanatsal öğrenme modellerine yer verebilir ve benimsetebilirler. Bu sanatsal faaliyetler sonucunda öğrencilerin hayal güçlerini ve düşüncelerini uygulamalarına, denemelerine ve çeşitli yaratıcı çözümler üretme gibi çabalar üzerine yoğunlaştırmaları mümkün olmaktadır (Artut, 2013). Bu anlamda sanat etkinleri sırasında çocuklara gözlem yapabilme, meraklarını uyandırma, keşfedebilme ve yaratıcı düşünebilme becerilerini kazandırarak görsel algılarının geliştirilebilmesi mümkündür.

Ders dışı öğrenme ortamlarında aktif öğrenme yöntemlerinin kullanılmasının, çocuğun kendisi ile çevresindeki yaşantılar arasında bağlantılar kurabilme olanağını sunabileceği için görsel algıyı da geliştirebileceği 
düşünülmektedir. Aktif öğrenme, sınıf ortamında öğreticinin aktif durumda sunduğu konuları veya bilgileri öğrencilerin pasif bir biçimde bilgileri ezbere aldığı geleneksel öğretimin tam tersidir (Meyers ve Jones, 1993). Geleneksel eğitimde ön planda tutulan ezbercilik tutumu, aktif öğrenme tekniğinde yerini araştırma, dikkatini kazanma, merak etme, deneyerek öğrenme ve uygulama yapma sürecine bırakmıştır. Müze ve sanat galeri ziyaretlerinin kreş veya anaokulu sınıfları dışında yapılması, çocukların merak duygusunu artırarak gözlem yapabilme imkanını verdiği için daha kalıcı beceriler geliştirebilmelerine yardımcı olacaktır.

İlgili alanyazında erken çocukluk döneminde görsel algıyı inceleyen gerek yurtiçinde gerekse yurtdışında birçok araştırma bulunmaktadır (Akaroğlu ve Dereli, 2012; Erben, 2005; Erdem Özat, 2010; Hines, 1971; Ikeda, Kasugai, Yamaguchi, Uchino, Katase ve Kanno, 2012; Yıldırım, Akman ve Alabay, 2012). Gerçekleştirilen araştırmalardan farklı olarak sanat etkinliklerinde aktif yöntemlerin kullanılmasının erken çocukluk döneminde görsel algıya etkisinin incelendiği bu çalışmanın diğer araştırmalardan farklı olduğu düşünülmektedir.

\subsection{Araştırmanın Amacı}

$\mathrm{Bu}$ araştırmanın amacı sanat galerisi ziyaretlerinde gerçekleştirilen aktif öğrenme etkinliklerinin okul öncesi 4-6 yaş grubu çocuklara uygulanmasının, onların görsel algılarına olan etkisini incelemektir. Araştırma amacı doğrultusunda ayrıca su sorulara da cevap aranmıştır.

1. Frostig Gelişimsel Görsel Algı Testine ilişkin kontrol ve deney gruplarına ait son test puanları için hesaplanan t-testi analizinin verileri deney grubu lehine midir?

2. Frostig görsel algı testine ilişkin grupların son test puan ortalamaları arasında anlamlı bir fark var mıdır?

\section{Yöntem}

\subsection{Araştırmanın Modeli}

Araştırma deneysel desen ile tasarlanmış, deney ve kontrol gruplarında drama yöntemine uygun şekilde hazırlanan uygulamalar, öğrencilerin eleştirel düşünmelerine yönelik etkileri deneysel model olan ön-test son-test kontrol gruplu model göz önünde bulundurularak düzenlenmiştir.

\section{2. Çalıșma Grubu}

Araştırma grubu, Erzurum İl Milli Eğitime bağlı 2018-2019 yılı Zübeyde Hanım Anaokulunda öğrenim gören 46 yaş grubu öğrencilerinden deney 15, kontrol 15 olmak üzere toplam 30 öğrenciden oluşturulmuştur. Araştırma grubunun eşliğinde oluşan bu süreçte deneysel çalışma 5 haftalık bir süreç içerisinde gerçekleştirilmiştir. Oluşturulan çalışma grubuna ilişkin bilgiler Tablo 1'de gösterilmiştir.

Tablo 1

Çalışma Grubuna İlişkin Bilgiler

\begin{tabular}{|c|c|c|c|c|}
\hline Değişken & & & f & $\%$ \\
\hline \multirow{4}{*}{ Cinsiyet } & \multirow[b]{2}{*}{ Deney } & $\mathrm{K} 1 \mathrm{z}$ & 7 & 45.7 \\
\hline & & Erkek & 8 & 53.3 \\
\hline & \multirow{2}{*}{ Kontrol } & $\mathrm{K} 1 \mathrm{z}$ & 4 & 26.7 \\
\hline & & Erkek & 11 & 73.3 \\
\hline
\end{tabular}

Tablo 1 incelendiğinde deney grubunda yer alan 15 öğrencinin 7'sinin kız (\%45.7), 8'inin erkek olduğu (\%53.3); kontrol grubunda yer alan 15 öğrencinin ise 4'ünün kız (\%26.7), 11'inin erkek olduğu görülmektedir.

\subsection{Verilerin Toplanması}

Veri toplama aracı olrak Frostig Gelişimsel Görsel Algı testi kullanılmıştır.

\subsubsection{Frostig Gelişimsel Görsel Algı Testi}

Frostig Görsel Algı testi Çocukların görsel algılarını ve okul hazır oluşlarını belirlemeye yardımcı olan testtir. Dr. Marianne Frostig tarafından geliştirilen bir performans testidir. Okulöncesi dönemde yapılan etkinlikler çocuğun karakterine ilişkin verdikleri bilgiye göre analiz edilebildiğinden Frostig gelişimsel görsel algı testin sonucunda altta yatan problemin olup olmadığının tespit edilmesinde büyük bir katkısı olacaktır. Özellikle özel öğrenme güçlüğü olan çocukların görsel algılamaları saptanabilir. Çocukların hazır bulunuşluk düzeyleri bilindiği sürece uygun akademik programlara karar verilebilir. Aral ve Ayhan (2016) tarafindan Türkçeye uyarlanmış ve araştırmalar sonucunda elde edilen bulgular Frostig Görsel Algı Testi'nin Türkçe formunun dört-altı yaşlar arasındaki çocuklar için geçerli ve güvenilir bir ölçme aracı olduğunu göstermiştir. 4-8 yaşları arasındaki çocuklara uygulanır. Testi bireysel ya da grup şeklinde uygulamak mümkündür. Testin hazırlığı ile uygulanması 50 dakika sürmektedir. 
Test beş alt testten oluşmaktadır;

1. Alt Test: Göz-Motor Koordinasyon (16 Soru)

2. Alt Test: Şekil-Zemin İlișkisi (8 Soru)

3. Alt Test: Şekil Değişmezliği/Sabitliği (32 soru)

4. Alt Test: Mekânda ki Pozisyon/ Mekân-Konum Algısı (8 soru)

5. Alt Test: Mekân İlişkilerinin Algılanması (8 soru)

\subsubsection{Materyal}

Testte kullanılan materyaller üçgen, kare, artı işareti, yıldız şekli, ay, oval, çember gibi şekillerden oluşan örnek kartlar ve renkli kalemlerden oluşmaktadır (mavi, kırmızı, kahverengi, sarı ve yeşil renklerde kalem ve kurşun kalem). Çocukların test sırasında düzeltme yapamamaları ve silgi kullanmamaları yönünde uyarılmaları gerekir.

Frostig Görsel Algı Testi grup ya da bireysel olarak 4-6 yaş arası çocuklara uygulanmaktadır. Bu testin 5 alt testi olup her soruda farklı yönergeler sunulmaktadır. Aşağıda her alt testin uygulamaların yapılışı ve yönergeleri verilmiştir:

1.Alt Test (Göz-Motor Koordinasyonu): Bu bölümde farklı genişlikte olan paralel çizgiler arasından başlangıç noktasından bitişe kadar kesintisiz, yatay, dikey, kıvrımlı ve açılı çizimler yapmayı içeren toplam 16 madde yer almaktadır. Burada materyal kurşun kalem ve kırmızı kalemdir. Testi yaptıran uzman, test kitapçığının ilk sayfasını açıp öğrenciye kâğıt üzerindeki fare ve peynir gösterilir. Fareyi bu iki paralel çizginin arasından çizgiye çarpmadan ve taşmadan kalemi kaldırmadan peynire ulaştırması istenir. Diğer benzer sorularda da aynen devam edilir. 10, 11, 12. ve 13. soruya gelince farklı bir oyun oynanacağı söylenir. Burada iki nokta bulunur ve o noktaları kalemle kaldırmadan düz bir çizgiyle birleştirilmesi istenir. 14. soruda kutunun içindeki iki nokta gösterilir ve bu noktaların birleştirilmesi istenir. 15. ve 16. soruda kutunun içerisinde üç tane noktalar bulunur ve bu noktaları 15. soruda aşağıdan yukarıya 16. soruda ise yukarıdan aşağıya doğru noktaları birleştirilmesi istenir. Bu I. Alt testin toplam maksimum puanı 30'dur. Her item 0-1-2 olarak puanlandırılmaktadır. Ancak 5. ve 9. item en fazla 1 puandır. Her soruda farklı yönergelerle birlikte test uygulanır.

2. Alt Test (Şekil-Zemin Ayrımı): Bu bölümde şekil-zemin ayrımı giderek karmaşıklaşan zeminler içinde şekli algılamayı içerir. Çocuğun karışık şekillerin içerisinden istenen geometrik şekillerinin bulması ve çizmeleri istenir. Bu testte kolaydan zora doğru sıralanmış 8 madde yer almaktadır. Bazı maddelerde beş şekil, bazılarında ise iki şekil bulunmaktadır. Burada materyal kırmızı, mavi, yeşil ve kahverengi kalemlerle birlikte 7 tane demonstrasyon kartlar (yıldız, üçgen, dikdörtgen, artı işareti, oval, ay, uçurtma) içerir. Testi uygulayan uzman, çocuklardan 1. 2. 3. ve 4. maddede karışık bir şekilde dizayn edilmiş şekillerde istenen geometrik şekilleri renkli kalemlerle çizilmesi istenir. 5. iki yıldız ve 6 . maddede ise 4 yıldızın olduğu belirtilip farklı renklerle çizilmesi istenir. 7. maddede uçurtma ve 8. maddede ise oval dairenin içinde gizlenmiş olup şeklin bulunması ve üzerinden çizilmesi istenir. Bu II. Alt testin toplam maksimum puanı 20'dir. $\mathrm{Bu}$ maddelerde bulunan her şekil 1 puan olarak değerlendirilmektedir. Her soruda farklı yönergelerle birlikte test uygulanır.

3. Alt Test (Şekil Sabitliğinin Algılanması): Bu alanda belirli geometrik şekillerin değişik büyüklük, duruş, gölgeleme ve pozisyonlarda algılanması ve benzer şekillerden ayırt edebilmesi yeteneğini ölçmeyi hedefleyen maddeler içerir. Bu alt teste çocukların bulması beklenen toplam 17 şekil vardır. Burada materyal yeşil ve kahverengi kalemlerle birlikte 4 tane demonstrasyon kartlar (kare, dikdörtgen, çember ve oval) içerir. Testi uygulayan uzman, çocuklara kartla ile kare, dikdörtgen, çember ve oval şekilleri tanıtılır ve yeşil kalemle o sayfada sadece gördüğü çemberleri ve kahverengi kalem ile sadece gördüğü karelerin kenarları çizmesi istenir. Bu III. Alt testin toplam maksimum 17 puandır. Her bulduğu ve doğru çizdiği şekil 1 puan, yanlış çizdiği şekil için ise -1 puan alır. Toplam puan eksiye düşerse bu alt testten sıfır alır.

4. Alt Test (Mekânda Konumun Algılanması): Bu alanda vücudun objelerle olan ilişkisini geliştirmektedir. Sağsol ayırımı, ters çevirme ve rotasyon ve eşleştirme yönergeleri vardır. Bu alt teste toplam 8 madde vardır. Testi uygulayan uzman, demonstrasyon kartındaki beş şekilden farklı olanı bulması istenir. Bulunca nedenini sorarız. Farklı olana çarpı attı̆gımızı belirtiriz. 1'den 4. soruya kadar olan şekillerde farklı olana çarpı atılması istenir. 5'ten 8'e kadar olan sorular için ise demonstrasyon kartı alınır, oradaki objenin diğer objelerden aynısı hangisi ise onun seçilmesi istenir ve üzerine çarpı atıldığını gösterir. Aynı durumu sorularda da uygulanması istenir. Bu IV. Alt testin toplam maksimum puanı 8 'dir. Her doğru işaretlenen obje için 1 puan verilir.

5. Alt Test (Mekân İlişkilerinin Algılanması): Bu alanda ise iki ya da daha fazla nesnenin kendisi ve diğeri ile olan ilişkilerini algılamayı içermektedir. Şekli oluşturan öğeleri analiz edebilme becerilerini ölçmeyi amaçlar. 8 madde bulunmaktadır. Testi uygulayan uzman, kâğıt üzerinde şekil gösterilir ve "Bu taraftaki şekli görüyor musun?" denir ve burada noktalar ve çizgileri var. Parmakla gösterilir ve çizginin üzerinden gidilir. Diğer tarafa geçilir "Bak burada noktalar var ama çizgiler yok." denir. Kalem ile o çizgileri çizmesi istenir. Bu V. Alt testin toplam maksimum puanı 8 ' dir. Her doğru çizilen çizgiler için 1 puan verilir. 
Bütün 5 alt testin toplam maksimum puanı 83'tür.

\subsubsection{Deneysel Süreç}

Programın uygulama aşamasına geçmeden önce deney ve kontrol gruplarına ön test olarak Frostig görsel algı testi uygulanmıştır.

2018-2019 eğitim öğretim yılının Nisan ayında kontrol grubu, hazırlanan programa dahil olmayıp öğretmenlerinin belli programına devam etmişlerdir. Deney grubuna ise hazırlanan sanat galerisi etkinlik programına aktif öğrenme teknikleri ile beraberinde 4 haftalık uygulama yapılmıştır. 4 hafta içinde yapılan uygulama aşağıda sıralanmıştır:

1. Hafta: Öncelikle öğrencilere Sanat galerisi hakkında bilgiler, dikkat edilmesi gerekenler, neler olabileceğine dair kısaca bilgilendirilme yapılmıştır. Öğrencilerden ziyaret esnasında sabırlı ve esnek olmaları istenir. Galeride sanat eserlerini dikkatlice gözlemleyerek kendi yaşamı ile bağdaştırması ve empati kurması beklentileri dile getirilir. Öğrencilerin merak duygusuna cevap olmak için kendilerinden soru sormaları ve hatta eleştirel düşünmeleri istenir. Bu haftaki aktif öğrenme tekniğinde "Nesi var?" tekniğine yer verilmiştir. Galeri salonundan bir kişi çıkarılır ve içeride ki öğrenciler bir resim seçer, bu resimde hangi renkler ve hangi geometrik şekillerinin olduğu konuşulur. Dişarıdaki öğrenci içeri seslenir ve seçilen resme göz atar, içerisinde neler olduğunu söyler eksik bir durum olursa öğrencilere "Nesi var?” sorusunu sorar ve öğrenciler ipucular verir ve eksiklileri tamamlar. Böylece tüm öğrencilere bu teknik uygulanıp birinci haftanın programı sona ermiştir.

2. Hafta: Programda aktif öğrenme tekniklerinden "Ben kimim?” etkinliğine yer verilmiştir. Bunun için sınıf ortamında bulunan öğrencilere Sanat galerisinde unutulan resimleri ön öğrenmeler olarak tekrar hatırlatmak için sınıftaki ekrandan tekrar gösterilmiş ve eserlerin sahipleri tanıtılmıştır. Öğrencilerden resimleri iyi gözlemlemesi istenir ve ekran kapatılır. Sınıftaki her öğrenciden beğendiği ve etkilendiği resmi hatırladığı kadarı ile çizmesi istenir. Çizim ve boyama işlemi bittikten sonra öğrenciler teker teker tahtaya çıkar yaptığı resmi arkadaşlarına gösterir ve "Ben kimim?" sorusunu yöneltir. Diğer öğrenciler ise o resme bakıp sahibi hatırlar. Bu etkinlik bilhassa beyin jimnastiği etkisi yaratmıştır.

3. Hafta: Bu hafta ki programda ise aktif öğrenme tekniklerinden oyun tarzında uygulanan “Tombala" etkinliğine yer verilmiştir. Sanat galerisinde bulunan, en beğenilen ya da detay içeren bir resim seçilir, fotoğrafı çekilir ve öğrencilere dağıtmak üzere renkli bir şekilde çıktısı alınır. Dağıtılan bu çıktıların yanında dile getirilen renk veya şekilleri kapatması için küçük bir kâğıt parçası yanlarında bulunur. Her öğrenci birbirinin kâğıdına bakmayacak şekilde oturma düzeni oluşturulur ve oyun başlar. Öğretmen o resimde neler olduğuna (mavi renk, kare, daire, kırmızı vs.) değinir ve öğrenciler onu görüyorsa yanlarında bulunan küçük kâğıt parçası ile kapatılır. İlk bitiren öğrenciye birinci çinko, ikinci bitirene ikinci çinko ve üçüncü bitirene ise çinko denir ve oyun biter. Böylece öğrencilere dikkat becerisini kazandıran bu teknikte öğrenilenlerin tekrar edilmesine de olanak sağlanmıştır.

4. Hafta: Son hafta olan bu programda ise aktif öğrenme tekniklerinden "Hazineyi Bul" etkinliğine yer verilmiştir. Sanat galerisinden bir resim seçilir, çıktısı alınır ve yap-boz tarzında küçük parçalara ayrılır. Ayrılan parçalar sınıfın farklı köşelerinde saklanır. Saklanan parçaların yerlerini belirten krokileri çizilir, öğrencilere dağıtılır. Grup haline gelen öğrenciler krokilere bakarak saklanan parçaları bulmaya çalışır, bir araya getirirler. Böylece etkinlik sona ermiştir.

4 haftalık sürecin sonunda deney ve kontrol grubuna son test olarak tekrar Frostig görsel algı testi uygulanmıştır. Böylece Sanat galerisi ziyaretlerinde gözlemlenen resimler ve uygulanan aktif ögrenme tekniklerinin Frostig görsel algılarına etkisini yapılan testlerin puanları ile veri analizi yaparak incelenmiştir.

\subsection{Verilerin Analizi}

Veriler analiz edilmeden önce parametrik testlerin varsayımları karşılayıp karşılamadığ SPSS 22.0 programı ile kontrol edilmiştir. Bu doğrultuda deney ve kontrol grubuna katılan öğrencilerin uygulama sonrasında test sonucunda belirlenen puanlarının normalliği Shapiro-Wilk normallik testi ile test edilmiştir. Ayrıca veri setinin basıklık ve çarpıklık (kurtosis-skewness) değerleri incelenmiştir.

Frostig Görsel Algı Testi toplam 72 soru içermektedir. Puanlama sürecinde her alt testin maksimum puanı vardır. Bunlar: Göz-motor koordinasyonu maksimum 28 puan, şekil-zemin ilişkisi maksimum 20 puan, şekil değişmezliği/sabitliği algısı maksimum 17 puan, mekândaki pozisyon/ mekân-konum algısı maksimum 8 puan ve mekân ilişkilerinin algılanması ise maksimum 8 puan olarak değerlendirilecektir. Bu testin verileri toplamda 81 puan üzerinden değerlendirilmektedir. Belirlenen puanlar sonrasında yüzdeye göre averaj puanları üzerinde değerlendirip gelişim düzeyleri hakkında bilgi verilir. 


\subsubsection{Frostig Görsel Algı Testine İlişkin Normallik Analizleri}

Deney ve kontrol grubuna katılan öğrencilerin uygulama sonrasında test sonucunda belirlenen puanlarının normal dağılıma uygun olup olmadığını test etmek amacıyla Shapiro-Wilk normallik testi yapılmış ve basıklık (kurtosis) ile çarpıklık (skewness) katsayı değerleri incelenmiştir. Sonuçlar Tablo 2, Tablo 3 ve Tablo 4'de yer almaktadır.

Tablo 2

Deney ve Kontrol Gruplarının Frostig Görsel Algı Testine İlişkin Ön Test Shapiro-Wilk Normallik Testi Sonuçları

\begin{tabular}{|c|c|c|c|c|}
\hline Değişken & Gruplar & İstatistik & sd & $\mathbf{p}$ \\
\hline \multirow{2}{*}{ Frostig Görsel Alg1 Testi } & Kontrol & .911 & 15 & .141 \\
\hline & Deney & .976 & 15 & .938 \\
\hline
\end{tabular}

Shapiro-Wilk normallik testi sonucunda Tablo 2'deki deney ve kontrol grubuna katılan öğrencilerin ön test puanlarına bakıldığında, ortalama puanların normal bir dağılıma sahip olduğu görülmektedir.

Tablo 3

Deney ve Kontrol Gruplarının Frostig Görsel Algı Testine İlişsin Son Test Shapiro-Wilk Normallik Testi Sonuçları

\begin{tabular}{|c|c|c|c|c|}
\hline Değișken & Gruplar & İstatistik & sd & p \\
\hline \multirow{2}{*}{ Frostig Görsel Alg1 Testi } & Kontrol & .961 & 15 & .717 \\
\hline & Deney & .962 & 15 & .727 \\
\hline
\end{tabular}

Shapiro-Wilk normallik testi sonucunda Tablo 3'deki deney ve kontrol grubuna katılan öğrencilerin uygulama öncesi ön test puanlarına bakıldığında, verilerin normal bir dağılıma sahip olduğu görülmektedir.

Deney ve kontrol gruplarının verilerinin normal dağılıma sahip olup olmadığına ilişkin bilgi edinmenin bir başka alternatifi, aritmetik ortalama $(\overline{\mathrm{X}})$ ve medyan ile basıklık (kurtosis) ve çarpıklık (skewness) katsayılarının irdelenmesidir. Araştırmalar boyunca elde edilen ön ve son test sonucunda ölçülen puanlara dayanarak aritmetik ortalama $(\overline{\mathrm{X}})$ ve medyan ile basıklık(kurtosis) ve çarpıklık(skewness) değerleri Tablo 4'de gösterilmiştir.

Tablo 4

Frostig Görsel Algı Testi Sonucunda Ön Test ve Son Test Puanların Normallik Değerleri

\begin{tabular}{lcccccc}
\hline & Gruplar & $\overline{\mathbf{X}}$ & Ss & Ortanca & Çarpıklık & Basıklık \\
\hline \multirow{3}{*}{ Frostig Görsel } & Kontrol Ön test & 56.40 & 8.06 & 57.00 & .135 & -1.452 \\
Alg1 Testi & Kontrol Son test & 59.07 & 8.69 & 57.00 & .148 & -1.007 \\
& Deney Ön test & 53.60 & 7.25 & 54.00 & -.297 & .580 \\
\hline
\end{tabular}

Deney ve kontrol gruplarının Frostig görsel alg1 testinden elde edilen puanların verileri Tablo 4'de gösterilmektedir. Bu verilere bakıldığında, aritmetik ortalama $(\bar{X})$ ve medyan verilerinin birbirine yaklaşık olduğu belirlenmiştir. Aynı zamanda basıklık (kurtosis) ve çarpıklık (skewness) değerlerinin $-1+1$ arasında olduğu tespit edilmiştir. Bu durum kabul edilebilir değerlerin sınırları içerisinde yer almaktadır. Deney ve kontrol gruplarından elde edilen bu verilerin sonucuna bakıldığında normal bir dağılım olduğu görülmektedir.

Bu tip araştırmaların en önemli noktası, doğru test kullanımına karar verilmesidir. Bu amaçla ilk aşamada deney ve kontrol gruplarında yer alan öğrencilerin, parametrik testlerin ve veri toplama araç puanlarının araştırma konusuna bağlı olarak oluşturulan varsayımlarını karşılayıp karşılayamadıkları gözden geçirilmiştir. Sonuç olarak ise normal dağılımın olduğu gözlemlenmiştir. Verilerin toplanması sonucunda dikkatle incelenen puanlar doğrultusunda yapılan normallik testlerinde veri setinde yer alan " $n$ ” yani birey (gözlem) sayısı 30'un altında yer almasından dolayı Shapiro-Wilk değerleri özellikle ele alınıp incelenmiştir. Aynı zamanda basıklık (kurtosis) ve çarpıklık (skewness) verilerinin -1, +1 değerleri arasında yer alması sonucunda verilerin normal dağılım gösterdiğini de göstermektedir. İstatistik programında yer alan mod kavramı minimum değeri ele alan mod değerleri, verilerin normal dağılıp dağılmadığı konusunda yanıltıcı sonuçlar verebileceğinden dikkate alınmamıştır.

Yapılan bu analizler doğrultusunda veri setlerinin normallik varsayımlarını karşılamış ve parametrik testlerden iki grubun karşılaştırılması sonucunda bağımsız örneklemler için t-testinin kullanılması uygun görülmüştür. Aynı zamanda uygulanan bu gruba ait iki ölçüm verilerine dayanarak bu puan ortalamalar arasındaki farklılığın belirlenmesinde bağımlı örneklemler için t-testi ve ön test-son test puanları arasında anlamlı farklılık olup olmadığını belirleyebilmek amacıyla Tek Faktörlü Kovaryans Analizi’nin (One Factor Analysis of CovarianceANCOVA) kullanılması uygun görülmüştür.

\subsubsection{Geçerlik ve Güvenirlik}

Frostig Görsel Algı Testinin güvenirliği, 1961 yılında Frostig, Lefever ve Whittlesey’in çalışmaları sonucunda test tekrar test yöntemi ile sınanmış ve sonuç olarak ise kararlılık kat sayısı 0,98 olarak belirlenmiştir. Geçerliliği için 
ise WICS testinin sözel bölümüne bakılarak I.Q ile Frostig Görsel Algı Testi arasındaki bağlantıya bakılarak bunun sonucunda; Göz-Motor Koordinasyonu alt testi ile 0,60; Şekil-Zemin Ayrımı alt testi ile 0,72; Şekil sabitliği alt testi ile 0,53; Mekân-Konum İlişkileri alt testi ile 0,50 ve son olarak Mekân İlişkileri alt testi ile 0,75 düzeyinde korelasyon elde edildiği gözlemlenmiştir (Sağol, 1998). Frostig Görsel Alg1 Testinin Türkçe formunun dört-yedi yaşlar arasındaki çocuklar için geçerli ve güvenilir bir ölçme aracı olduğu ifade edilmiştir (Aral ve Ayhan, 2016).

\section{Bulgular}

Bu bölümde kontrol ve deney gruplarına yapılan çalışmaların sonucuna bağlı olarak, sanat galerisi ziyaretinde gerçekleştirilen aktif öğrenme tekniklerinin (bağımsız değişkenlerin), çocukların görsel algılarına (bağımlı değişkene) olan etkisini belirlemek amacıyla Frostig Görsel Alg1 Testi sonucunda elde edilen verilerin analizlerine yer verilmiştir.

\subsection{Birinci Alt Probleme İlişkin Bulgular}

Kontrol ve deney gruplarının denkliği baz alınarak yapılan ön test sonuçları arasında farklılığın olup olmadığına dair veri analizleri Tablo 5'de gösterilmiştir.

Tablo 5

Kontrol ve Deney Gruplarına Ait Ön Test Puanları İçin Hesaplanan T-Testi Analizinin Verileri

\begin{tabular}{lcccccc}
\hline Gruplar & n & $\overline{\mathbf{X}}$ & ss & sd & t & \multirow{2}{*}{ p } \\
\hline Kontrol Grubunun Ön Testi & 15 & 56.40 & 8.06 & 28 & \multirow{2}{*}{1.000} \\
Deney Grubunun Ön Testi & 15 & 53.60 & 7.25 & 28 & \multirow{2}{*}{326} \\
\hline
\end{tabular}

Tablo 5'de kontrol ve deney gruplarının Frostig Gelişimsel Görsel Algı Testi uygulama öncesi ön test puanlarının serbestlik dereceleri (sd), puan ortalamaları $(\overline{\mathrm{X}})$, standart sapmaları (Ss) ve t-testi sonuçları gösterilmektedir. Kontrol ve deney grubunun uygulama öncesinde elde edilen veri sonuçlarına dayanarak yapılan bağımsız örneklemler için t-testi analizi verilerine göre grupların ön test ortalamaları arasında herhangi bir farklılığa rastlanılmamıştır $\left(\mathrm{t}_{(28)}=1.000, \mathrm{p}>0.05\right)$. Bu durum grupların Frostig görsel algıları açısından aynı düzey kriterlere ait olduğunu göstermektedir.

Sanat galerisi ziyaretinde aktif öğrenme etkinliği uygulanan deney grubunun son testi ile etkinliğin uygulanmadı̆̆ kontrol grubunun son testi arasında anlamlı bir farklılık olup olmadığına ilişkin veri analizleri Tablo 6'da yer almaktadir.

Tablo 6

Kontrol ve Deney Gruplarına Ait Son Test Puanları İçin Hesaplanan T-Testi Analizinin Verileri

\begin{tabular}{|c|c|c|c|c|c|c|}
\hline Gruplar & $\mathbf{n}$ & $\overline{\mathbf{X}}$ & ss & sd & $\mathbf{t}$ & p \\
\hline Kontrol Grubunun Son Testi & 15 & 59.07 & 10.26 & 20 & & ח \\
\hline Deney Grubunun Son Testi & 15 & 70.73 & 5.16 & 28 & -3.935 & .000 \\
\hline
\end{tabular}

Tablo 6'da kontrol ve deney gruplarının Frostig Gelişimsel Görsel Algı Testi uygulama sonrası son test puanlarının serbestlik dereceleri (sd), puan ortalamaları $(\bar{X})$, standart sapmaları (Ss) ve bağımsız örneklemler için t-testi analizinin sonuçları yer almaktadır. Kontrol ve deney grubunun bağımsız örneklemler için t-testi analizi sonuçlarına bakıldığında grupların son test puanlarının istatiksel ortalamaları arasında anlamlı farklılığa rastlanmıştır $\left(\mathrm{t}_{(28)}=-3.935, \mathrm{p}<0.05\right)$. Bu bağlamda her iki grubun son test toplam puanlarının aritmetik ortalamalarına bakıldığında, ortaya çıkan farklılığın deney grubunda olduğu anlaşılmaktadır $\left(\overline{\mathrm{X}}_{\text {Deney }}=70.73\right.$; $\left(\overline{\mathrm{X}}_{\text {Kontrol }}=59.07\right)$.

Kontrol grubuna ait ön ve son test puanlarının farklılık gösterip göstermediğini belirlemek için yapılan bağımlı grup t-testi sonuçları Tablo 7'de verilmiştir.

Tablo 7

Kontrol Grubuna Ait Ön Test ve Son Test Puanları İçin Hesaplanan T-Testi Analizinin Verileri

\begin{tabular}{lcccccc}
\hline Kontrol Grubu & $\mathbf{n}$ & $\overline{\mathbf{X}}$ & ss & sd & t & p \\
\hline Ön Test & 15 & 56.40 & 8.06 & 14 & -1.747 & .103 \\
Son Test & 15 & 59.07 & 10.26 & 14 & \\
\hline
\end{tabular}

Tablo 7'de kontrol grubunun Frostig Görsel Algı Testi ön test ve son test puanlarının serbestlik dereceleri (sd), puan ortalamaları $(\overline{\mathrm{X}})$, standart sapmaları $(\mathrm{Ss})$ ve bağımlı grup t-testi analizinin sonuçları yer almaktadır. Etkinliğe dahil edilmeyen kontrol grubunun hem ön test hem de son test bağımlı grup t-testi sonucuna göre, grubun ön test ile son test puanları arasında anlamlı farklılığa rastlanılmamıştır $\left(\mathrm{t}_{(14)}=-1.747, \mathrm{p}>0.05\right)$.

Deney grubunun ön test ve son test puanlarının farklılık gösterip göstermediğini belirlemek için yapılan bağımlı grup t-testi sonuçları Tablo 8'de gösterilmiştir. 
Tablo 81

Deney Grubuna Ait Ön Test ve Son Test Puanları İçin Yapılan Bağımlı T-Testi Analizinin Verileri

\begin{tabular}{lcccccc}
\hline Gruplar & $\mathbf{n}$ & $\overline{\mathbf{X}}$ & ss & sd & $\mathbf{t}$ & $\mathbf{p}$ \\
\hline Ön Test & 15 & 56.30 & 7.25 & \multirow{2}{*}{14} & -8.683 \\
Son Test & 15 & 70.73 & 5.16 & & .000 \\
\hline
\end{tabular}

Tablo 8'de deney grubunun Frostig Görsel Algı Testi ön test ve son test puanlarının serbestlik dereceleri (sd), puan ortalamaları $(\overline{\mathrm{X}})$, standart sapmaları $(\mathrm{Ss})$ ve bağımlı grup t-testi analizinin sonuçları gösterilmiştir. Deney grubuna uygulanan Sanat galerisi ziyaretlerinde yapılan aktif öğrenme tekniğinin etkisini anlamak üzere uygulamaya yer verilmeden önce uzman eşliğinde ön test ve ardından 4 haftalık uygulama sonrasında yapılan uzman eşliğinde son test puanlarının arasında farklılığın bulunup bulunulmadığını tespit edebilmek için yapılan bağımlı grup t-testi sonucuna göre, ön test ile son test puanları arasında anlamlı farklılığa rastlanılmıştır $\left(\mathrm{t}_{(14)}=-8.683, \mathrm{p}<0.05\right)$. Deney grubuna ait ön test ile son test puanlarının istatiksel ortalamaları göz önünde bulundurulduğunda asıl farklılığın son testte olduğu anlaşılmaktadır $\left(\overline{\mathrm{X}}_{\text {Öntest }}=56.30 ; \overline{\mathrm{X}}_{\text {Sontest }}=70.73\right)$.

Sanat galerisi ziyaretlerinde aktif öğrenme etkinliklerinin, çocukların görsel algılarına olan etkisini kavrayabilmek ve bağımlı değişkenlerin bulunduğu örneklemde ön testin etkisini irdeleyebilmek amaciyla ANCOVA, yani tek faktörlü olan kovaryans analizi yapılmıştır. Kovaryans analizi yapılması için, bu analizin ön şartlarından biri regresyon eğimlerinin eşteşliğidir. Bu bağlamda regresyon eğimlerinin eşteşliği şartının sağlanıp sağlanmadığını anlayabilmek için incelemeler yapılmış ve sonuçlar Tablo 9'da değerlendirilip gösterilmiştir.

Tablo 9

Frostig Görsel Alg1 Testin İçin Regresyon Eğimin Göstergesi

\begin{tabular}{|c|c|c|c|c|c|c|}
\hline & Kaynak & Kareler Top. & Sd & Kareler Ort. & $\mathbf{F}$ & p \\
\hline & Düzeltilmiş Model & 1609.183 & 3 & 536.394 & 12.353 & .000 \\
\hline & Sabit & 688.503 & 1 & 688.503 & 15.856 & .000 \\
\hline & Grup & 308.867 & 1 & 308.867 & 7.113 & .013 \\
\hline Frostig Görsel & Ön test & 442.876 & 1 & 442.876 & 10.199 & .004 \\
\hline \multirow[t]{4}{*}{ Alg1 Testi } & Grup*Ön test & 170.883 & 1 & 170.883 & 3.935 & .058 \\
\hline & Hata & 1128.984 & 26 & 43.422 & & \\
\hline & Toplam & 130139.000 & 30 & & & \\
\hline & Düzeltilmiş Toplam & 2738.167 & 29 & & & \\
\hline
\end{tabular}

Tablo 9'a bakıldığında regresyon eğimlerinin eşitliği şartının sağlanmış olduğu görülmektedir. Frostig Görsel Alg1 Testi regresyon eğimi göstergesine bakıldığında Grup*Ön test hizasında yer alan "p" verilerinin farklılık göstermemesi $(\mathrm{p}>.05)$ beklenmektedir. $\mathrm{Bu}$ doğrultuda regresyon eğimlerinin eşteşliğinin elde edildiği $(\mathrm{p}=.058>.05)$ görülmektedir. Aynı zamanda kovaryans hesaplaması ile bu istenen koşul sağlanmıştır $(\mathrm{F}=3.935$, $\mathrm{p}>.05)$.

Kovaryans hesaplamasına göre, aktif öğrenme etkinliklerinin, çocukların görsel algılarına etkisine yönelik kontrol ile deney gruplarının eşitliğine ilişkin hesaplanan ön test puanlarının farklılık gösterip göstermediğine yönelik veri analizi Tablo 10'da gösterilmiştir.

Tablo 102

Kontrol ve Deney Gruplarına Ait Ön Test Puanları İçin Hesaplanan T-Testi Analizinin Verileri

\begin{tabular}{lcccccc}
\hline Gruplar & $\mathbf{n}$ & $\overline{\mathbf{X}}$ & Ss & sd & T & p \\
\hline Kontrol Grubunun Ön Testi & 15 & 56.40 & 8.06 & 28 & 1.000 & .326 \\
Deney Grubunun Ön Testi & 15 & 53.60 & 7.25 & 28 & \\
\hline
\end{tabular}

Tablo 10'da kontrol ve deney gruplarının Frostig Gelişimsel Görsel Alg1 Testi ön test puanlarının serbestlik dereceleri $(\mathrm{Sd})$, puan ortalamaları $(\overline{\mathrm{X}})$, standart sapmaları $(\mathrm{Ss})$ ve bağımsız grup t-testi analizinin sonuçları gösterilmiştir. Kontrol ile deney grupları bağımsız örneklemler için t-testi sonuçlarına göre, grupların ön test puan ortalamaları arasında farklılık olmadığ 1 saptanmıştır $\left(\mathrm{t}_{(28)}=1.000, \mathrm{p}>0.05\right)$. Elde edilen bu sonuç, grupların görsel algıları açısından birbirleriyle aynı düzeyde olduğunu veya benzer nitelikler taşıdığını göstermektedir.

Ön test puanlarına göre düzeltilmiş kontrol ve deney gruplarına ait son test puan hesaplamaları Tablo 11'de gösterilmiştir.

Tablo 11

Ön Teste Ait Puanlara Göre Düzeltilmiş Son Test Puan Ortalamaları

\begin{tabular}{lcccc}
\hline & Grup & $\mathbf{n}$ & $\overline{\mathbf{X}}$ & Düzeltilmiş ortalama \\
\hline \multirow{2}{*}{ Frostig Görsel Alg1 Testi } & Kontrol & 15 & 59.60 & 58.82 \\
& Deney & 15 & 70.73 & 71.51 \\
\hline
\end{tabular}


Tablo 11 incelendiğinde, çocukların Frostig görsel algı testine ilişkin son test puan ortalamalarına göre, deney grubunun $\bar{X}=70.73$, kontrol grubunun ise $\bar{X}=59.60$ olduğu görülmektedir. Fakat "düzeltilmiş ortalama" adı altında deney grubu için hesaplanan son test puan istatiksel ortalaması $\bar{X}=71,51$ olarak gözükmüştür. Kontrol grubu için ise hesaplanan puan istatiksel ortalamasının $\overline{\mathrm{X}}=58.82$ olduğu görülmektedir.

\section{2. İkinci Alt Probleme İlişkin Bulgular}

Frostig Görsel Algı testinin son test puan sonuçları ile düzeltilmiş istatiksel puan ortalamaları için iki grubun tamamı ele alındığında deney grubu son test puan ortalamaları ve kontrol grubu son test puan ortalamalarına göre, deney grubu ortalamasının kontrol grubundan daha yüksek olduğu açıkça görülmektedir. Grupların hesaplanan son test verileri dikkate alındığında puanlar arasında gözlenen farkın anlamlı değer verip vermediğine dair bilgi elde etmek için hesaplanan kovaryans analizinin verileri Tablo 12'de gösterilmiştir.

Tablo 12

Frostig Görsel Alg1 Testi Ön Test Etkisinin Kontrol Altında Tutulduğu Kovaryans Analizinin Verileri

\begin{tabular}{|c|c|c|c|c|c|c|c|}
\hline & Kaynak & Kareler Toplamı & sd & Kareler Ortalaması & $\mathbf{F}$ & p & $\eta 2$ \\
\hline \multirow{7}{*}{$\begin{array}{l}\text { Frostig Görsel } \\
\text { Alg1 Testi }\end{array}$} & Düzeltilmiş Model & 1438.300 & 2 & 719.150 & 14.938 & .000 & .525 \\
\hline & Sabit & 638.925 & 1 & 638.925 & 13.271 & .001 & .330 \\
\hline & Ön test & 508.667 & 1 & 508.667 & 10.566 & .003 & .281 \\
\hline & Grup & 1166.140 & 1 & 1166.140 & 24.222 & .000 & .473 \\
\hline & Hata & 1299.866 & 27 & 48.143 & & & \\
\hline & Toplam & 130139.000 & 30 & & & & \\
\hline & Düzeltilmiș Toplam & 2738.167 & 29 & & & & \\
\hline
\end{tabular}

Tablo 12'de grupların son test puan ortalamaları arasında gözlenen farkın anlamlı olup olmadığına ilişkin yapılan kovaryans hesaplama sonuçlarına bakıldığında, gruplar arasında ön test puanlarına göre düzeltilmiş son test puanları arasında $\left(\mathrm{F}_{(1,27)}=24.222, \mathrm{p}=.000, \eta 2=.473\right)$ anlamlı bir fark olduğu tespit edilmiş ve bu farklılığın deney grubunda olduğu $\left(\overline{\mathrm{X}}_{\text {Deney }}=71.51, \overline{\mathrm{X}}_{\text {Kontrol }}=58.82\right)$ tespit edilmiştir. Bu analizlerin sonucunda elde edilen etki büyüklüğü ise aktif öğrenme etkinliklerinin, çocukların görsel algılarındaki varyansın \%47'sini açıklamıştır.

\section{Sonuç ve Tartışma}

$\mathrm{Bu}$ araştırma; anaokuluna devam eden 4-6 yaş arası çocukların sanat galerisi ziyaretlerinde aktif öğrenme tekniklerinin yer alması ile beraberinde araştırmacı tarafından geliştirilen Frostig Görsel Algı Testi ile görsel algılarına etkisini ve farklılık yaratıp yaratmadığını incelemek amacıyla yapılmıştır. Araştırmacı tarafından görsel algılamanın göz-motor koordinasyonu, şekil zemin ilişkisi, şekil sabitliği, mekan-konum ilişkisi ve mekan ilişkileri alt boyutlarına yönelik aktif öğrenme tekniklerinde: Nesi var?, Ben kimim?, Hazineyi Bul ve Tombala etkinliği uygulanmıştır.

Araştırmada, uygulama öncesinde anaokulunda oluşturulan deney ve kontrol gruplarının Frostig görsel algıları açısından aynı düzey kriterlere sahip olduğu gözlemlenmiştir. Bu durum deney ve kontrol grubunun eşit bir şekilde araştırmaya dahil edildiğinin göstergesi olmuştur.

Araştırmada deney ve kontrol gruplarına ilişkin yapılan bağımsız örneklemler için t-testi analiz sonucuna göre grupların son test puan ortalamaları arasında anlamlı farklılı̆̆a rastlandığı görülmüştür. Grupların son test puan ortalamaları incelendiğinde farklılığın deney grubu lehine olduğu anlaşılmaktadır. Bu sonuç, Bezrukikh ve Terebova'nın (2009) araştırma sonuçları ile benzerlik taşımaktadır. Bu durum uygulanan programın deney grubu lehine etkili olduğunun göstergesidir. Bu durumda kontrol grubu öğrencilerinin hazırlanan program dişında normal eğitim programına devam ederken görsel algıları için birçok önemli noktayı kaçırmış olduğu görülmektedir.

Araştırmada kontrol grubunun ön test ve son test puanları arasında farklılık olup olmadığına ilişkin yapılan bağımlı örneklemler için t-testi analizi sonucuna göre grubun ön test ve son test puan ortalamaları arasında anlamlı bir farklılığa rastlanmadığı görülmüştür. Bu durum sanat galerisi ziyaretinde gerçekleştirilen aktif öğrenme etkinliğine katılmayan kontrol grubu ögrencilerinin okulun normal eğitim programına devam ederken görsel alg1 gelişimlerinde herhangi bir değişikliğe rastlanmadığını göstermektedir.

Araştırmada Frostig Görsel Alg1 Testi uygulama sonrası verilerin çözümlenmesinden elde edilen sonuçlara göre uygulanan programın genel anlamda deney grubunun ön test ve son test veri analizlerinde anlamlı farklılıklar ortaya çıkardığı tespit edilmiştir. Bu bağlamda uygulanan programın çocukların görsel algı gelişimleri üzerinde etkili olduğu düşünülmektedir. Öğrenci görüşlerine bakıldığında ise, uygulanan programın sanat galerisi ziyaretlerini sevdirdiği, çocuklar üzerinde bir takım istenen davranışları kazandırdığı, dikkat konusunda renkler ve şekiller üzerinde gelişim sağladığı görülmüştür. Bu anlamda elde edilen sonuçları destekleyen farklı araştırmalarda bulunmaktadır (Akaroğlu, 2014).

Alanda konu ile ilgili yapılan araştırmalar, okulöncesi dönemdeki çocukların görsel algılarının ve becerilerinin gelişmesinin desteklenmesi için okul eğitim programı haricinde uygulanan sanat galeri ziyaretlerinde resimler 
üzerinde uygulanan aktif öğrenme tekniklerinin, çocukların görsel algı düzeylerinde olumlu yönde etki yarattığını göstermiştir. Trussell'ın (2013) Frostig görsel alg1 gelişim testi ve Lincoln-Oseretsky Motor gelişim ölçeklerini kullanarak ilkokul birinci ve ikinci sınıfların okuma başarılarındaki performans puanlarına etkilerini incelediği araştırma sonuçları görsel, motor ve okuma fonksiyonları arasında herhangi bir ilişkiye rastlanmadığını göstermiştir. Bu anlamda bu araştırma Trussell'in araştırma sonuçları ile farklılık göstermektedir. Buna karşı Cengiz (2002), Linn (1968), Yüksel ve Kılıçgün (2012) ve Tuğrul, Erkan, Aral ve Etikan'ın (2002) çalışmalarında 5-6 yaş grubuna uyguladıkları "Görsel Algı Gelişimini Destekleyici Eğitim Programı"nın, Turan'ın (2006), anasınıfına devam eden çocukların görsel algılama alt boyutlarında, Kaya'nın (1989) benzer konu olan anaokuluna devam eden çocukların görsel algılama becerilerinde ve Kılıç'ın (2004) ailesiyle birlikte yaşayan ve yuvada yaşayan çocuklar arasında evde kalanların lehine olacak şekilde görsel algılarının gelişimini artırdığını ortaya koymuştur. Akaroğlu ve Dereli (2012) tarafından eğitici oyuncaklar kullanılarak verilen görsel alg1 eğitiminin çocukların görsel algı becerilerinde olumlu etki yarattığ sanat eğitiminin görsel algıya etkisini araştıran yayınlar da bulunmaktadır. Görener'in (2006) erken çocukluk döneminde yapılandırılmış sanat eğitiminin görsel algılaya etkisini incelediği araştırma sonucuna göre Frostig Gelişimsel Görsel Algı Testi alt alanlarında anlamlı bir gelişme gösterdiği görülmüştür. Görener’in araştırması ile gerçekleştirilen bu araştırma özellikle deneysel süreç içerisinde uygulanan farklı yaklaşımlar bakımından birbirine benzememekle birlikte her iki araştırmada da sonuç olarak görsel algının gelişiminde olumlu bir artış olduğu belirlenmiştir.

Araştırma sonucunda ortaya konulan temel nokta, çocukların görsel algılarında üst düzey becerilere sahip olmalarının ilerideki okul yaşantılarına olumlu yönde etki etmesidir. Bu nedenle erken çocukluk döneminde öğrencilerin algılarını artıracak uygulamaların desteklenmesi büyük bir önem taşımaktadır. Araştırmada elde edilen bulgular ışı̆̆ında şu önerilerde bulunulmaktadır:

1. Okulöncesinde uygulanan eğitim programlarında, çocukların temelinin önemi göz önüne alınarak görsel alg1 gelişimlerine de katkı sağlayacak eğitim müfredatına yer verilmesi gerektiği düşünülmektedir.

2. Eğitim-öğretim sürecinde sanatsal faaliyetlere okulöncesi dönemden başlayıp, öğrencinin sanat sevgisi ve yaratıcı düzeyinin gelişimi için görsel algılama dersinin eğitim programında yer alması gerektiği düşünülmektedir. Bu anlamda küçük yaşlardan başlayarak görsel algının gelişiminde imgesel düşünmenin ve sanatsal faaliyetlerin etkisinin önemi olduğu düşünülmektedir.

3. Yapılan sanat galeri ziyaretinde aktif öğrenme tekniğinin uygulanmasıyla öğrencilerden istenilen davranış ve kazanımların elde edilmesine bağlı olarak, okullarda böyle uygulamaların ve etkinliklerin düzenlenmesinin öğrencilerin görsel algı gelişimleri açısından faydalı olacağı düşünülmektedir. Bunun için eğitimciler, galeriler ve okulların ortak bir şekilde yürüteceği çalışmalarla bu etkinliklerin zamanla gelenek haline getirilmesinin faydalı olacağı düşünülmektedir. $\mathrm{Bu}$ durum toplumumuzda yaygınlaşan ve gelişen sanat ortamının oluşmasını sağlayabilir.

4. Sanat galerisi ziyaretleri, okulöncesi dönemde yapılan birçok sosyal faaliyetlerin içerisinde de yer alabilir. Bu durum çocuklarda sanatsal ve estetiksel yaklaşım ile yaratıcılığın gelişmesine olanak sağlayabilir.

\section{Kaynakça}

Akaroğlu, E. G., \& Dereli, E. (2012). Okul öncesi çocukların görsel algı eğitimlerine yönelik geliştirilmiş eğitici oyuncakların çocukların görsel algılarına etkisi. Journal of World of Turks. 4(1). 201-222. Erişim adresi: http://www.dieweltdertuerken.org/index.php/ZfWT/article/view/265/akaroglu-dereli

Akaroğlu, E. G. (2014). Sanat ĕ̆itim programının 6 yaş çocuklarının görsel algı düzeylerine etkisi (Doktora tezi). YÖK tez veri tabanından erişildi (Tez No. 377787).

Aral, N., \& Ayhan, A. B. (2016). Frostig görsel alg1 testinin Türkçeye uyarlanması. The Journal of Academic Social Science Studies, 50, 1-22. doi: http://dx.doi.org/10.9761/JASSS3587

Artut, K. (2013). Sanat eğitimi kuramları ve öğretimi (7. baskı). Ankara: Anı Yayıncılık.

Athey, C. (1990) Extending thought in young children: A parent-teacher partnership. London: Paul Chapman Publishing.

Bezrukikh, M. M., \& Terebova, N. N. (2009). Characteristics of the development of visual perception in five to seven year old children. Human Physiology, 35, 684-689. doi: https://doi.org/10.1134/S0362119709060048

Bilir, Ş., \& Alpaslan, B. (1977). Çocuk gelişimi ve eğitimi el kitabı. Ankara: Hacettepe Üniversitesi Yayınevi.

Burunner, H., \& Tanker, P. (1978). Mesleki latince. Ankara: Ankara Üniversitesi Eczacılık Fakültesi Yayınları. 
Cengiz, Ö. (2002). 5,6-6 yaş çocuklarının görsel algl gelişimini destekleyici ĕ̆itim programının etkisi (Yüksek Lisans Tezi). YÖK tez veri tabanından erişildi (Tez No. 117459).

Erben, S. (2005). Montessori materyallerinin zihin engelli ve işitme engelli çocukların alıcı dil gelişiminden görsel algı düzeylerine etkisi (Yüksek Lisans Tezi). YÖK tez veri tabanından erişildi (Tez No. 190583).

Erdem Özat, N. (2010). Ö̆grenme güçlüğü yaşayan çocuklarda frostig görsel algl eğitim programının etkisi. (Yüksek Lisans Tezi). YÖK tez veri tabanından erişildi (Tez No. 263447).

Ertan, N., (2013). Okul öncesi çağdaki çocukların duygusal düzenleme ve baş etme stratejileri arasındaki ilişkinin, çaba sarf ederek kendini denetleme aracılı̆̆ıla incelenmesi (Yüksek Lisans Tezi). YÖK tez veri tabanından erişildi (Tez No. 358117).

Fişek, G. O., \& Yıldırım, S. M. (1983). Çocuk gelişimi. İstanbul: MEB Yayınları.

Frostig, M. (1968). Pictures and patterns: Teacher's guide. Viyana: Follet.

Gal, H., \& Linchevski, L. (2010). To see or not to see: Analyzing difficulties in geometry from the perspective of visual perception. Educational Studies in Mathematics, 74(2), 163-183. Erişim adresi: https://www.jstor.org/stable/40603201

Gander, M. J., \& Gardiner, H. W. (2014). Çocuk ve ergen gelişimi (6. baskı). Ankara: İmge Kitabevi.

Görener, Ö. (2006). Beş- altı yaş grubu çocuklarda yapılandırılmış görsel sanat ĕgitiminin görsel algılamaya etkisinin incelenmesi (Yüksek Lisans Tezi). YÖK tez veri tabanından erişildi (Tez No. 195875).

Hines, B. W. (1971). Analysis of visual perception of children in the appalachia preschool education program (Techinical Report 16). Division of Research and Evaluation Appalachia Educational Laboratary. Erişim adresi: https://files.eric.ed.gov/fulltext/ED062019.pdf

Ikeda, K., Kasugai, H., Yamaguchi, A., Uchino, Y., Katase, H., \& Kanno, A. (2012). Visual perceptual strengths and weaknesses in adults with intellectual disabilities compared with a birth year-matched norm. Journal of Intellectual Disability Research, 57(1), 67-79. doi: https://doi.org/10.1111/j.1365-2788.2011.01516.x

Kaya, Ö. (1989). Frostig görsel algılama ĕgitim programının anaokulu çocuklarının görsel algılama ve zihinsel gelişimlerine etkisi (Yayınlanmamış Yüksek Lisans Tezi). Hacettepe Üniversitesi, Ankara.

Kılıç, Ö. G. (2004). Ailesiyle birlikte yaşayan ve çocuk yuvasında kalan çocukların görsel algılama davranışı ile okul olgunluğu arasındaki ilişkinin incelenmesi (Yayınlanmamış Yüksek Lisans Tezi). Ankara Üniversitesi Fen Bilimleri Enstitüsü, Ankara.

Linn, S. H. (1968). A follow up: achievement of first- grade students after visual- perceptional training in kindergarten. Academic Therapy Quarterly, 3(3), 179-185.

Mangır, M., \& Çağatay, N. (1990). Anasınıfi ve anaokuluna devam eden beş altı yaş çocukların görsel algılama ve zekâ ilişkisinin incelenmesi. Ankara: Ankara Üniversitesi Ziraat Fakültesi Yayınları. Erişim adresi: https://dspace.ankara.edu.tr/xmlui/bitstream/handle/20.500.12575/68294/be \%c5\% $\%$ f $\% 20$ alt $\%$ c4\%b1\%20ya $\%$ c5\%9f\%20\%c3\%a7ocuklar\%c4\%b1 n\%20g\%c3\%b6rsel\%20alg\%c4\%b1lamas\%c4\%b1.pdf?sequence=1\&is Allowed $=\mathrm{y}$

Marriott, G. R. (2000). Developmental differences in visual-motor integration in children from 4 to 6-years-old on the kindergarten diagnostic instrument second edition (Ph.D. dissertation). United States Texas: Texas Woman's University ProQuest Digital Dissertations database (osu9993955).

Matthews, J. (2003). Drawing and painting. London: Cromwell Press.

Meyers, C., \& Jones, T. B. (1993). Promoting active learning: strategies for the college classroom. San Francisco: Jossey-Bass Publishers.

Rosenblum, S. (2006). The development and standardization of the children activity scales. (ChAS-P/T) for the early identification of children with developmental coordination disorders. Child: Care, Health and Development, 32, 619-632. doi: https://doi.org/10.1111/j.1365-2214.2006.00687.x

Sağol, U. (1998). Down sendromlu çocukların görsel algl gelişimine frostig görsel algı programının etkisi (Yüksek lisans tezi). YÖK tez veri tabanından erişildi (Tez No. 74150).

Sahasrabudhe, P. (2006). Design for learning through the arts. International Journal of Education Through Art, 11(2), 77-84 
Sortor, J. M., \& Kulp, M. T. (2003). Are the results of the Beery-Buktenica developmental test of visual-Motor integration and its subtest related to achievement test scores? Optometry \& Vision Science, 80, 758-763. doi: https://doi.org/10.1097/00006324-200311000-00013

Trevarthen, C. (1995) Mother and baby-seeing artfully eye to eye. (R. Gregory, J. Harris, P. Heard and D. Rose, Eds.), In the artful eye (p. 157-200). Oxford: Oxford University Press.

Tuğrul, B., Erkan, S., Aral, N., \& Etikan, İ. (2002). Altı yaşındaki çocukların görsel algılama düzeylerine Frostig gelişimsel görsel alg1 eğitim programının etkisinin incelenmesi. Journal of Qofquaz University, 8, 67-85. Erişim adresi: https://docplayer.biz.tr/5615589-Alti-yasindaki-cocuklarin-gorsel-algilama-duzeylerinefrostig-gelisimsel-gorsel-algi-egitim-programinin-etkisinin-incelenmesi.html

Turan, D. E. (2006). Alt sosyo-ekonomik düzeyde anasınıfina devam eden ve etmeyen 60-71 ay çocuklarında görsel algılama davranışının incelenmesi (Yüksek Lisans Tezi). YÖK tez veri tabanından erişildi (Tez No. 206161).

Wolf, D., \& Fucigna, C. (1983). Representation before picturing. Paper presented at the Symposium on Drawing Development, British Psychological Society International Conference on Psychology and the Arts, University of Cardiff, Wales.

Yıldırım, S., Akman, B., \& Alabay, E. (2012). Okul öncesi dönem çocuklarına sunulan montesorri ve mandala eğitiminin görsel algılama davranışlarına etkisinin incelenmesi. Buca Eğitim Fakültesi Dergisi, 32, 92-103. Erişim adresi: https://dergipark.org.tr/tr/pub/deubefd/issue/25119/265243

Yüksel, M. Y., \& Kılıçgün, M. Y. (2012). Okul öncesi eğitim kurumuna devam eden 4-5 yaş grubu çocukların görsel alg1 gelişimlerine frostig gelişimsel görsel alg1 eğitim programının etkisi. M.Ü. Atatürk Eğitim Fakültesi Eğitim Bilimleri Dergisi, 36(36), 193-211. Erişim adresi: https://dergipark.org.tr/tr/pub/maruaebd/issue/374/ 2602 